\title{
The effect of acidifier and phytase on thyroid weight as related to short-chain fatty acid concentration in the caeca of broiler chickens*
}

\author{
A. Mieczkowska, J. Czerwiński and S. Smulikowska ${ }^{1}$ \\ The Kielanowski Institute of Animal Physiology and Nutrition, \\ Polish Academy of Sciences \\ 05-110 Jabłonna, Poland
}

\begin{abstract}
The experiment was carried out on 96 female broilers, allocated to 8 groups of 12 birds, kept in individual cages. Two wheat- and soyabean meal-based diets containing $150 \mathrm{~g} / \mathrm{kg}$ of rapeseed expeller cake were formulated, with $\mathrm{Ca}$ and P levels of 9 and $7.1 \mathrm{~g} / \mathrm{kg}$ (diet $\mathrm{H}$ ) or 7.9 and $5.9 \mathrm{~g} / \mathrm{kg}$ (diet L), respectively. The diets were unsupplemented or supplemented with phytase $(1000 \mathrm{U} / \mathrm{kg})$ and/or acidifier $(6 \mathrm{~g} / \mathrm{kg})$ and were fed from day 8 to 28 of life. At the end of the experiment the chickens were killed and dissected, the thyroids were weighed, and caecal digesta was collected for short-chain fatty acid (SCFA) analysis.

Supplementation of diets with phytase or acidifier significantly increased thyroid weight by $16 \%$ $(\mathrm{P}<0.01)$ and $11 \%(\mathrm{P}<0.05)$, respectively. The increase in thyroid weight due to phytase supplementation was greater at the lower dietary $\mathrm{Ca}$ and $\mathrm{P}$ levels, and the greatest when the acidifier was also added to the diet. The thyroid weight did not, however, correlate with either the total SCFA concentration or with the ratio of individual SCFAs in the caecal digesta.
\end{abstract}

KEY WORDS: acidifier, phytase, thyroid, short-chain fatty acids, caecal digesta, broiler chickens

\section{INTRODUCTION}

In rapeseed, from 60 to $80 \%$ of phosphorus occurs as phytates, which may negatively affect the availability of minerals and digestion of protein. It was found previously (Smulikowska et al., 2006) that supplementation of diets containing untoasted rapeseed cake with phytase induced enlargement of thyroids in broiler chickens. This may be due to the enhancement of bacterial activity stimulated by the input of nutrients released by phytase from various complexes in the lower parts of

\footnotetext{
* Supported by the Polish Ministry for Scientific Research and Information Technology, Grant No. 2 P06Z 03428

${ }^{1}$ Corresponding author: e-mail: s.smulikowska@ifzz.pan.pl
} 
the intestinal tract. The important role of gut microflora in glucosinolate metabolism was demonstrated by Nugon-Baudon et al. (1990) and Campbell et al. (1995). They found that dietary glucosinolates were excreted intact in germ-free rats, while in rats with normal microflora, the majority of these compounds disappeared from the digestive tract. The enlarged thyroids, liver and kidneys of these animals pointed to the toxicity of glucosinolate derivatives. In a previous trial (Smulikowska et al., 2006), apart from the last week of life, broiler diets contained an antibiotic growth promoter and coccidiostatic, which prevents microflora overgrowth to some extent. It may be expected that the effects of phytase on the activation of goitrogenic compounds from cold pressed rapeseed cake may be more important when antibiotic-free diets are fed. The objective of this study was to determine whether supplementation of a diet containing rapeseed cake with phytase and acidifier would affect the activity of caecal microflora and influence the relative thyroid weight.

\section{MATERIAL AND METHODS}

Ninety-six 8-day-old broiler females were divided into 8 groups, 12 birds per group, and placed in individual cages. Chickens were given cold pelleted experimental diets based on wheat, maize, rapeseed expeller cake $(150 \mathrm{~g} / \mathrm{kg})$, and soyabean meal. Diets contained $220 \mathrm{~g} \mathrm{CP} / \mathrm{kg}$ and $12.8 \mathrm{MJ} \mathrm{ME} / \mathrm{kg}$. The experimental design consisted of a $2 \times 2 \times 2$ factorial arrangement of the treatments with two $\mathrm{Ca}$ and $\mathrm{P}$ concentrations due to a reduced amount of dicalcium phosphate (diet H 9 or $7.1 \mathrm{~g} / \mathrm{kg}$, diet L 7.9 or $5.9 \mathrm{~g} / \mathrm{kg}$ of $\mathrm{Ca}$ or $\mathrm{P}$, respectively), two levels of supplemental phytase ( 0 or 1000 $\mathrm{U} / \mathrm{kg}$; Natuphos 5000, BASF) and two levels ( 0 or $6 \mathrm{~g} / \mathrm{kg}$ ) of acidifier (Calprona P5, Verdugt B.V.), which contained lactic, formic and citric acids and their Ca salts. Diets did not contain antibiotic growth promoter. The birds were provided experimental diets and water ad libitum, feed intake and body weight were measured for 3 weeks. At the end of the experiment the chickens were killed, thyroids were excised and weighed. Caecal digesta were collected from 7 birds per group, its $\mathrm{pH}$ was measured and adjusted to 8.0. Caecal contents were stored at $-20^{\circ} \mathrm{C}$ until analysis for short-chain fatty acids (SCFA) according to Ziołecki and Kwiatkowska (1973) using isocaproic acid as an internal standard on a HP 5890 AII gas chromatograph equipped with a Supelco Nukol capillary column $(30 \mathrm{~m} \times 0.25 \mathrm{~mm}$ internal diameter, film $0.25 \mathrm{~mm})$. The initial column temperature was set at $100^{\circ} \mathrm{C}$ for $2 \mathrm{~min}$, increased to 140 at $10^{\circ} \mathrm{C} /$ min and held at the final temperature for $20 \mathrm{~min}$. Data were analysed as a $2 \times 2 \times 2$ factorial arrangement using Statgraphics Plus ver. 5.1.

\section{RESULTS AND DISCUSSION}

Phytase supplementation significantly increased feed intake and body weight gain by 6 and $5 \%$, respectively, while the decrease in the dietary $\mathrm{Ca}$ and $\mathrm{P}$ content 
and supplementation of the diets with acidifier did not significantly influence either parameter (data not shown). Thyroid weight increased $(\mathrm{P}<0.05)$ after supplementation of the diets with phytase, similarly as in our previous study (Smulikowska et al., 2006). It also increased $(\mathrm{P}<0.01)$ due to supplementation with the acidifier (Table 1). Analysis of interactions revealed that the increase in thyroid weight due to phytase supplementation was greater at the lower dietary $\mathrm{Ca}$ and $\mathrm{P}$ levels $(\mathrm{HL} \times \mathrm{Phy} ; \mathrm{P}<0.05)$ and the greatest when the acidifier was added to the $\operatorname{diet}(\mathrm{Phy} \times \mathrm{A} ; \mathrm{P}<0.01)$.

Table 1. Effect of phytase (Phy) and acidifier (A) and the level of dietary Ca and P (H - 9 and $7.1 \mathrm{~g} / \mathrm{kg}, \mathrm{L}-7.9$ and $5.9 \mathrm{~g} / \mathrm{kg}$, respectively) on thyroid weight, total short-chain fatty acid (SCFA) content and percentage of individual acids in total SCFA

\begin{tabular}{lcccccccccc}
\hline \multirow{2}{*}{ Item } & \multirow{2}{*}{ Phy } & \multicolumn{2}{c}{$0 \mathrm{~g} / \mathrm{kg} \mathrm{A}$} & \multicolumn{3}{c}{$6 \mathrm{~g} / \mathrm{kg} \mathrm{A}$} & \multirow{2}{*}{ RMSE } & \multicolumn{3}{c}{ Probability } \\
\cline { 3 - 6 } \cline { 5 - 9 } & & $\mathrm{H}$ & $\mathrm{L}$ & $\mathrm{H}$ & $\mathrm{L}$ & & Phy & $\mathrm{A}$ & $\mathrm{H} \mathrm{L}^{*}$ \\
\hline Thyroid weight $^{1}$, & - & 12.1 & 12.4 & 14.3 & 13.4 & 1.02 & 0.05 & 0.006 & 0.31 \\
g/100 g BW & + & 11.8 & 14.7 & 15.5 & 16.0 & & & & \\
pH of caecal contents $^{2}$ & - & 6.01 & 6.22 & 6.47 & 6.31 & 0.12 & 0.95 & 0.058 & 0.853 \\
& + & 6.20 & 6.24 & 6.30 & 6.25 & & & &
\end{tabular}

Total SCFA in caecal digesta, $\mu M / g$ wet digesta and the ratio of individual acids in \%

\begin{tabular}{|c|c|c|c|c|c|c|c|c|c|}
\hline \multirow[t]{2}{*}{ total $\mathrm{SCFA}^{3}$} & - & 145 & 104 & 128 & 95 & 6.53 & 0.20 & 0.59 & 0.001 \\
\hline & + & 118 & 112 & 139 & 127 & & & & \\
\hline \multirow[t]{2}{*}{ acetic $\operatorname{acid}^{4}$} & - & 51.1 & 52.3 & 58.6 & 56.4 & 1.50 & 0.25 & 0.51 & 0.90 \\
\hline & + & 56.7 & 60.5 & 56.7 & 55.0 & & & & \\
\hline \multirow[t]{2}{*}{ propionic acid ${ }^{5}$} & - & 2.27 & 2.02 & 2.47 & 2.37 & 0.01 & 0.04 & 0.46 & 0.24 \\
\hline & + & 2.38 & 1.92 & 1.65 & 1.51 & & & & \\
\hline \multirow[t]{2}{*}{ butyric acid ${ }^{6}$} & - & 17.0 & 14.6 & 15.9 & 16.3 & 0.54 & 0.20 & 0.17 & 0.01 \\
\hline & + & 15.0 & 16.1 & 17.6 & 18.0 & & & & \\
\hline \multirow[t]{2}{*}{ isobutyric acid ${ }^{7}$} & - & 13.2 & 16.9 & 10.3 & 11.6 & 1.08 & 0.20 & 0.21 & 0.52 \\
\hline & + & 10.9 & 9.7 & 9.9 & 10.8 & & & & \\
\hline \multirow[t]{2}{*}{ valeric acid $^{8}$} & - & 10.2 & 8.6 & 7.1 & 7.9 & 0.19 & 0.59 & 0.21 & 0.42 \\
\hline & + & 9.7 & 6.4 & 7.2 & 8.7 & & & & \\
\hline \multirow[t]{2}{*}{ isovaleric acid ${ }^{9}$} & - & 6.2 & 8.3 & 5.6 & 7.9 & 0.18 & 0.23 & 0.83 & 0.40 \\
\hline & + & 5.2 & 5.3 & 6.9 & 8.7 & & & & \\
\hline
\end{tabular}

RMSE - residual mean square error; the following interactions were significant at $* \mathrm{P}<0.05 ;{ }^{*} \mathrm{P}<0.01$; ***P $<0.001:{ }^{1} \mathrm{HL} \times$ Phy*, Phy $\times \mathrm{A}^{* * *} ;{ }^{3} \mathrm{HL} \times$ Phy**, Phy $\times \mathrm{A}^{* *},{ }^{5}$ Phy $\times \mathrm{A}^{*} ;{ }^{6} \mathrm{HL} \times$ Phy* Phy $\times$ $\mathrm{A}^{*} ;{ }^{7} \mathrm{Phy} \times \mathrm{A}^{*} ;{ }^{8} \mathrm{~A} \times \mathrm{HL}^{*} ;{ }^{2,4,9}$ all interactions insignificant

The thyroid weight did not, however, correlate with the total SCFA concentration in the caecal digesta, nor with the ratio of individual SCFA (Table 1). It was hypothesized, on the basis of Nugon-Baudon et al. (1990) and Campbell et al. (1995), that the input of nutrients released by phytase from various complexes in the lower parts of the intestinal tract may stimulate bacterial activity in the gut. The 
enlarged thyroids of broilers in the present study pointed to the increased toxicity of glucosinolate derivatives. Validation of this hypothesis was difficult, however, due to the high individual variability in the caecal SCFA concentration within a group. It is also possible that the ileal microflora may be involved in glucosinolate hydrolysis, but this activity was not measured in the present study. In general, the SCFA concentration in the caecal digesta was lower at a lower dietary $\mathrm{Ca}$ and $\mathrm{P}$ level, and increased after phytase supplementation, with the exception of diet $\mathrm{H}$ without acidifier $(\mathrm{HL} \times \mathrm{Phy}, \mathrm{P}<0.05$, Phy $\times \mathrm{A} ; \mathrm{P}<0.001)$. The SCFA concentration did not significantly affect the $\mathrm{pH}$ of the caecal digesta (Table 1 ).

\section{CONCLUSIONS}

It may be concluded that in the absence of a dietary antibiotic growth promoter, phytase and acidifier supplementation of diets containing rapeseed cake did not cause significant overgrowth of caecal microflora in broiler chickens.

\section{REFERENCES}

Campbell L.D., Słominski B.A., Nugon-Baudon L., Rabot S., Lory S., Quinsac A., Krouti M., Ribaillier D., 1995. Studies on intestinal tract glucosinolate content, xenobiotic metabolizing enzymes and thyroid status in germ-free and conventional rats fed rapeseed meal. Proceedings of 9th International Rapeseed Congress, Cambridge (UK), Vol. 1, 209-211

Nugon-Baudon L., Rabot S., Wal J.-M., Szylit O., 1990. Interaction of the intestinal microflora with glucosinolates in rapeseed meal toxicity: first evidence of an intestinal Lactobacillus possessing a myrosinase-like activity in vivo. J. Sci. Food Agr. 52, 547-559

Smulikowska S., Mieczkowska A., Czerwiński J., Weremko D., Nguyen C.V., 2006. Effect of exogenous phytase in chickens fed diets with differently processed rapeseed expeller cakes. J. Anim. Feed Sci. 15, 237-252

Statgraphics ${ }^{\circledR}$ ver. 5.1., 1994-2001. Statistical Graphic System by Statistical Graphic Corp.

Ziołecki A., Kwiatkowska E., 1973. Gas chromatography of $\mathrm{C}_{1}$ to $\mathrm{C}_{5}$ fatty acids in rumen fluid and fermentation media. J. Chromatogr. 80, 250-254 